\title{
Religious Origins of Democracies and Dictatorships
}

Theocharis Grigoriadis

School of Business \& Economics

Discussion Paper

Economics

$2013 / 16$ 


\title{
Religious Origins of Democracies and Dictatorships
}

\author{
Theocharis Grigoriadis*
}

Abstract: In this paper, I argue that religion matters for the emergence of democracies and dictatorships. Religion is defined as demand for public goods. Different types of religious collectives reflect different tradeoffs between centralized resource distribution and market rewards. Religions are defined as collectivist, when their respective collectives facilitate the hierarchical provision of common pool resources toward their members at the expense of market incentives. Religions are defined as individualist, when their respective collectives recruit and preserve their members on the basis of market incentives. Islam, Orthodoxy and Catholicism are treated as collectivist religions, whereas Judaism and Protestantism as individualist ones. I provide a historical overview that designates the Jewish kibbutz as the collective of democracy and the Russian-Orthodox monastery as the collective of dictatorship. Assuming a collectivist economy, I solve the radical government and modernization infinitely repeated games. Modernization occurs when the threat of a radical government is imminent and when the leader has high extraction rents over the economy. In order to stay in power, the leader credibly commits to provide more public goods in the future, and thus modernization occurs. Underdevelopment occurs at intermediate levels of state enforcement, modernization at low levels and centralization at high levels of state enforcement. The emergence of a radical government is always likely in a collectivist economy.

Keywords: democracy, dictatorship, collectivism, individualism, modernization, Orthodoxy, Judaism

JEL: D72, D73, D78, P21, P26, P32, P51, Z12

\section{Introduction}

How does religion influence the emergence of political regimes? Can distinct religious traditions condition differential paths to modernization? Are some religions more conducive to authoritarianism than others? And what are the religious determinants, if any, of political transitions? In this paper, I argue that religion is a core element in the analysis of transitions to democracy and dictatorship. Religion matters for democracy and dictatorship, because it shapes the demand for public goods of citizens and thus imposes a constraint on the leader's tradeoff between personal rents and public goods provision. The economic organization of Eastern

\footnotetext{
* Department of Economics and Institute of East European Studies, Free University of Berlin, Germany (theocharis.grigoriadis@fu-berlin.de).
} 
Orthodox and Roman Catholic monasteries as well as of Muslim tariqas indicates the relationship between religion and hierarchical provision of public goods, central planning in the distribution of common resources, immediate supervision of individual performance and lack of a right to exit. On the contrary, the economic organization of the Jewish kibbutz and the Protestant parish suggests that religious membership and distribution of common pool resources can be identified with market incentives, a competitive insurance scheme and a right to exit the collective.

In this paper, I focus on the distributive ethics and membership rules of the Eastern Orthodox monastery and the Jewish kibbutz. The choice of these two types of religious organizations is not incidental. First, they constitute two diametrically different models of resource distribution on the market-plan dimension; kibbutz leadership sets the threshold for individual contributions toward the common pool, but at the same time it is checked for its decisions through the direct democracy procedures of the kibbutz assembly. On the contrary, the abbot can never be checked by the members of the Eastern Orthodox monastery; his administrative status depends on the approval and continuous support by the local bishop or the patriarch. While abstinence from property rights is common grounds both for the monastery and the kibbutz, in the monastery there is no compensatory mechanism for that effect. Candidate monks are required to transfer contractually all their property to the monastery in order to be admitted to the collective. The charismatic authority of the abbot and the absolute degree of dependence on his monitoring set the institutional roots for societal and state building that has the propensity to authoritarianism, corruption and asymmetric public goods contributions. Nevertheless, arbitrariness in the management of collective goods can lead faster to the dissolution of the collective per se rather than to the replacement of its dissident members.

Hence, democracy is more likely in a society, when the institutional prerogatives of the dominant religion advance collective interests without requiring the sacrifice of individual welfare. The relationship between civil and social welfare rights in the constitutions of Western Europe and the current debate on the provision of social welfare in the United States identifies social welfare and administrative commitment to the provision of public goods as complementary to the respect and protection of individual liberties. Similarly dictatorship is more likely in a society, when the institutional features of the dominant religion treat collective interests and 
individual welfare as orthogonal. The assumption here is that the higher the degree of individual sacrifice the better off is society as a whole. What can prevent this hierarchy from collapsing or revealing the pathologies of central planning is the commitment of its leader to deliver a minimum of public goods without taking into account the contributions of other members that rank lower in the hierarchy.

The paper is structured as follows. In section 2 I discuss the literature on transition, democratization and modernization and link it to religious norms and public goods distribution. In section 3 I provide a historical overview of the Jewish kibbutz and the Eastern Orthodox monastery as economic systems and analyze their propensity to democracy and dictatorship respectively. In section 4 I setup and solve the radical government and modernization games; I draw inferences about the emergence of radical government and modernization when citizen protests against the government are imminent and the government can only commit to the future provision of more public goods in order to preserve its authority. Section 5 concludes.

\section{Literature}

Weber's Protestant Ethic suggests that religious norms shape economic behavior, rather than the other way round; rational organization of free labor and regularized investment of capital condition the emergence of a capitalist enterprise (2002). Thus, Protestant asceticism is more inclined to lead to higher degrees of productivity and economic growth (2002). Modernization theory analyzes the impact of industrialization on state formation and regime change. Lipset argues that economic development and democratization are inherently related; there is no industrialization without a shift to more representative forms of government (1959). Rostow suggests that states transition to industrial market structures by developing a leading industrial sector; this condition generates a spillover effect that modernizes politically and economically the whole society (1959). Unlike the linear approaches of Rostow and Lipset, Gerschenkron proposes that the later the transition from backwardness to industrial market structure, the higher the demand for capital; moreover, the later the timing of industrial transformation, the more important is the role of the state in generating the capital required (1965). 
Religious norms have a direct impact on the provision of public goods. The existence of different public goods thresholds create differentiated conditions for regime stability and regime change. Acemoglu and Robinson in their seminal book on the Economic Origins of Dictatorship and Democracy argue that revolution occurs under conditions of high inequality and low cost of revolution (2006). Moreover, to prevent revolution elites are usually faced with three choices: 1. Repression, 2. Democratization and 3. Compromised redistribution (2006). It is clear that Acemoglu and Robinson understand regime durability as an efficient social contract between the rich and the poor. The status quo is preserved as long as the rich are taxing themselves sufficiently enough to keep the poor happy. The model of patronage, prevalent in Latin American politics and its transitions, is obvious here. The material interests of the poor and the wealthy define the decision of the former to revolt or abstain and the latter to repress or compromise. The transition from backwardness to modernization is inherently related to political transition. Acemoglu and Robinson make the argument that democratic consolidation occurs when distributive policies are effective and there is an absence of religious and ethnic polarization in society (2007).

In my argument, leadership matters and religious norms constrain the set of decision strategies for the government. The leader is cognizant of the religious norms that the majority shares and delivers public goods in order to preserve his post. There is no significant difference between backwardness and industrial market structure with respect to the government's formal commitment to public goods provision. Inglehart and Baker indicate that traditional values persist despite the broad cultural consequences of industrialization in all modern societies (2000). Instead of looking at the religious norms held by popular majorities, they take states as their main unit of analysis and conclude that state structures rather than religious denominations shape the direction of traditional values in the society (Inglehart and Baker, 2000).

I define collectivism as state commitment to collective welfare. This is why I put religious traditions on the collectivism-individualism continuum. Differential degrees of economic collectivism lead to parallel tracks of modernization and thus to different institutional arrangements. Islam is considered to be the most collectivist of the five religious traditions presented in my chapter; Muslim leaders face the highest level of distributive obligations vis-à-vis their political audience. If collective welfare is treated as a constraint to modernization, then it 
becomes obvious why modernization does not generate institutional convergence across religious boundaries. A Protestant leader is more likely to maximize his personal and political rents by advancing modernization. Modernization theory holds in Protestantism, because leaders are punished only when they fail to treat collective welfare as second order condition of civil rights and personal profit. A Jewish leader is faced with a finite term horizon, when he is unable to enforce individual punishment for the loss of collective compliance rents, because he exposes his people to divine punishment. A Roman Catholic leader is more likely to last in power, only if he abides by the social contract he had agreed to with the business sector and the working classes. Tripartite economic structures and their preservation are keys to the reelection of Roman Catholic leaders or the maintenance of their office tenure. An Eastern Orthodox leader loses his office, when he treats the public sector and its bureaucracy as pillars for the generation of his own private wealth or the wealth of a particular class. A Muslim leader undermines his political horizon, when he violates the principles of religious law.

Lipset compares the United States with Canada to suggest that when the dominant religion in a country is more collectivist, the size of government is likely to be bigger (1993). This is the reason why Canada has a bigger government than the United States (Lipset, 1993). Eckstein argues that the long-run effects of revolutionary transformation are more inclined to lead to political and economic outcomes similar to the pre-revolutionary status quo due to cultural reasons (1992). Hence, religion matters for transitions from backwardness to an industrial steady state and thus modernization. I treat democracy as the regime equivalent of modernization. Desai et al. suggest that an autocrat cares about maintaining popular support for his policies and therefore he will offer the least costly bundle of welfare and political benefits to the people; the bundle of real political liberalization will always be more costly for him (2009). They correctly identify the existence of an authoritarian bargain between the citizens and the autocrat; however, they offer no explanation - cultural, social or political - why legitimacy is a decisive factor for authoritarian survival (Desai, 2009). Legitimacy is not just a factor defining how much an authoritarian government will spend to secure public support; beyond material incentives, people legitimize governments that abide by specific cultural values, as these are reflected in the multi-level provision of public goods. Public sector wages is an outdated proxy for measuring the purchase of 
public support by nondemocratic regimes. The latter's heavily bureaucratized structure and multitask organizational subsystems require a much more complex level of analysis. Moreover, Desai et al. are wrong, when they say that an increase in a regime's repressive capacity reduces the provision of welfare benefits and political rights; on the contrary, it allows the government to target more freely multiple social groups to consolidate this favorable for it equilibrium (2009).

The tradeoff between collective welfare and individual profit is crucial in my analysis of political economic equilibria. The treatment of religious collectives as economic systems with differential levels of welfare provision is essential for explaining the effects of religion on economic and political transitions. Hierarchy, discipline, monitoring and solidarity at the level of the collective define the reservation utilities of citizens and the enforcement capacity of the state. That way, religion becomes relevant for political economy. The existence of hierarchical and networked religions can consistently explain correspondences between religious traditions and political regimes.

This is what sets my definition of public goods authoritarianism: the inclusion of cultural beliefs in the authoritarian bargain that may reduce the marginal cost of distribution even under conditions of inelastic labor supply and be conducive rather than opposing to regime survival. In the following part of my paper, I focus on Judaism and Eastern Orthodoxy and explain why the Jewish kibbutz and the Eastern Orthodox monastery can be analyzed as the institutional prototypes of democracy and dictatorship.

\section{Institutional Prototypes of Democracy and Dictatorship}

\section{i. Market Incentives and Community Formation in the Jewish Kibbutz}

The influence of religious norms on political regimes can be traced in multiple ways: through the interaction between religious and secular legal orders, the penetration of bureaucratic institutions by religious values and practices, and the treatment of religious collectives as prototype economic systems that shape economic organization and policy. In this part, I focus on the latter path. First, I define the religious collective as an economic system in Eastern Orthodoxy 
and Judaism. Second, I identify the linkages between religious collectivism and political economy in Russia and Israel, states with an Eastern Orthodox and a Jewish majority respectively.

The image of the Halutz (pioneer) necessitated indifference to wages, material benefits, socio-economic status and political power (Eisenstadt, 1967: 117). Manual work and self-reliance were the other two elements that shaped communal life among the Jews of Palestine and up to the emergence of the Israeli state (Eisenstadt, 1967: 117). The introduction of these three principles into Israeli society occurred in multifaceted ways. First, it became the basis for the creation and dissemination of kibbutzim and moshavim (Eisenstadt, 1967: 119-121). Second, the structure of labor institutions such as the General Federation of Labor (Histadrut) was influenced by pioneer principles (Eisenstadt, 1967: 121). In moshavim and particularly kibbutzim, individual survival has been a first-order condition with respect to collective welfare.

Helman in his analysis of the kibbutz as a model of socialist economic organization argues that there are two significant elements that differentiate the kibbutz from a centrally planned economic system: 1 . The voluntary character of its membership and 2. The democratic nature of collective procedures, which are regulated by a general assembly formed by all adult kibbutz members (1992: 169-170). Exit from the kibbutz, particularly by younger people, is treated is a proof of the flawed system of incentives that defines its function (Helman, 1992: 177178).Hierarchical monitoring and control, complementarity of individual and collective interests and information-sharing can model kibbutz productivity as a moral hazard problem and thus eliminate some of its central planning elements that force some of its most competent members to exit (Helman, 1992: 180).

In his model of the kibbutz, Abramitzky identifies the trade-off between redistribution and voluntary participation; more productive individuals are less incentivized to stay than less productive ones (2008). And higher equality tends to provide more insurance to all kibbutz members at the expense of the more productive ones (2008). Nevertheless, wealthier kibbutzim offer higher incentives to their more productive members to stay rather than exit; as Abramitzky makes clear, the wealthier the kibbutz, the more equal its members and the more likely it is to retain its hard-working individuals (2008: 1126-1127). Thus, kibbutzim can offer optimal insurance and reduce the opportunity costs for their members, when participation to their communal 
structures comes along with the option of exit (2008: 1149-1152). While the allocation of resources is centralized, the exit option can make the kibbutz the best of both worlds, with both very high levels of equality and a competitive incentives scheme for its more productive individuals.

The absence of private property in the kibbutz is compensated with the right to exit. Moreover, there is no central authority that sets a common baseline for resource distribution and monitoring across kibbutzim, despite the efforts in Israel to create one at the national level (Weisman, 1996). Opportunity cost for any kibbutz member is treated as the kibbutz membership cost, which should be less than the social benefits incurred at the individual level, so that the kibbutz continues to exist for more than one period. Furthermore, the incentive to work is inherently linked with the valuation of work as a self-fulfilling process (Putterman, 1983: 157-188). This work ethic is what may motivate individuals to optimize their utility in terms of community contributions (Putterman, 1983: 173-177). Normative commitments are seen by Putterman as explanatory factors of kibbutz membership at the absence of property rights and material rewards; ideology rather than altruism accounts for organizational cohesion and mutual assistance (Putterman, 1983).

Transparent voting procedures and the requirement of two-thirds majority for the admission of new members ensures the coexistence of democracy with collectivism (Schwartz, 1957: 137-139). Individual responsibility is not constrained by collective property and freedom of expression is not undermined by egalitarian distribution (Schwartz, 147). This is why the Jewish kibbutz can be defined as the religious collective of democracy and an institutional prototype for mutually reinforcing community formation and market incentives.

Ruffle and Sosis provide interesting experimental evidence on cooperative behavior and ingroup-out-group bias between kibbutz members and city residents (2006). They argue that kibbutz members are willing to sacrifice more and thus are more cooperative when they are paired with other kibbutz members, where the opposite holds, when they are paired with city residents (2006: 154). They also find that newer kibbutz members are more cooperative than older kibbutz members and that kibbutz members become much less cooperative per se, when they are paired with city residents (2006: 157-158). Therefore, kibbutzim rely on the cooperative behavior of their newer members and can afford that way the more individualist approach of their more senior 
members. Similarly, egalitarian distribution in the kibbutzim has not been stable or always successful; evidence from the 1980s shows that, while the equality in terms of living standards remained relatively low, wealth and income inequality became significantly high (Amiel et al., 1996: 80).

At this point, it is important to stress the distinction between secular and Orthodox Judaism and their relationship to economic success. Fishman observes that the kibbutzim integrated to the Religious Kibbutz Federation - only a 6 percent of the total kibbutz population performed much better than those belonged to secular federations. ${ }^{1}$ Continuing this line of thought, Fishman and Goldschmidt argue that Max Weber and Werner Sombart were correct when they identified Judaism's interaction with economic success in capitalism (1990: 506-507). Their metrics of comparative economic performance are drawn from financial data including short- and long-run output, returns to capital and labor (1990: 508). They conclude that the Judaic principles of self-control and rational spending combined with solidarity and individual responsibility can account for the economic success of Orthodox kibbutzim (1990: 511).

In the Jewish kibbutz, the identification of an equilibrium point between communal and individual interests puts an upper limit to individual initiative and optimization of personal rents. Similarly, voluntary participation puts a lower limit to managerial control and corrects for hierarchical inefficiencies. The kibbutz as a political and economic system suggests a prototype institution for the State of Israel, whose democratic polity is explicitly defined by Judaic norms and rabbinical traditions. Ben-Ner observes that consumption in the kibbutz can serve both collective and private ends, and each kibbutz member faces a two-level optimization problem: at communal and individual levels (1987). Kibbutzim leaders optimize overall economic performance by treating members' individual rents as a system of external constraints.

I propose that Israel as political and economic system reflects the unstable set of points between collectivism and individualism, community formation and market incentives, welfare state and liberal market economy with a clear commitment toward political representation and

\footnotetext{
1 There is a reference to Fishman's 1983 Social Forces article in Fishman Ariyei and Yaaqov Goldschmidt. "The Orthodox Kibbutzim and Economic Success", Journal for the Scientific Study of Religion, Vol. 29, No. 4, December 1990: 505-511.
} 
protection of individual rights. Hence, the kibbutzim suggest a set of institutional and economic arrangements, which form the basis on which Israel is modeled as a political and economic system.

\section{ii. Authoritarian Welfare in the Eastern Orthodox Monastery}

The Jewish kibbutz is designated as the collective of democracy, because it offers competitive insurance schemes to its members, in order to facilitate their participation to collective work and the distribution of common resources in the absence of individual property rights. The Russian-Orthodox monastery is designated as the collective of dictatorship, because it offers no real exit option and provides to the abbot the absolute authority in the distribution of common resources and the enforcement of contribution standards.

Byzantine monasticism has been instrumental in consolidating the victory of iconophiles against iconoclasts and provides the normative foundations of Orthodox monasticism within and beyond the boundaries of the Byzantine Empire: personal poverty, obedience to the abbot, constant work and liturgical life (Meyendorff, 1974: 46-48). Moreover, the dogmatic divide between East and West about the nature of the Trinity revealed the theological commitment of the Eastern Church to the personal interpretation as a society of persons rather than as single philosophical essence (Meyendorff, 1974: 60-61). The position of Theodore the Studite toward the institutionalization of divorce and the mystery of Eucharist indicates also two more key principles of Orthodox communal life: 1. Acceptance of sin as human weakness and necessary precondition for salvation, and 2. The treatment of Eucharist as the core of Orthodox communitarian life and linkage between monks and laymen, the sacred and the profane (Meyendorff, 1974: 197-199 and 203-204).

The development of monasticism in the aftermath of iconoclasm consolidated the incorporation of ecclesiastical principles into state structures (Schemann, 1963). Monasteries became epicenters of intellectual production and political influence, the number of monks grew exponentially and monastic figures became central in Byzantine politics, as this is indicated by the case of Studion and its founder Theodore in Constantinople (Schemann, 1963). Rather than treating religion as a critique to the secular state, Byzantine monks became the consciousness of the empire itself. The inseparability between the basic functions of the Church and the legitimacy of 
the State does not qualify middle Byzantium either as theocracy or caesaropapist state; the latter has been extensively argued by Max Weber and his disciples. On the contrary, the spiritual influence of monastic theology on domestic politics and the ability of the Church to contest the legitimacy of executive authority in a non-democratic political environment show that Byzantine rulers had to take into account a double constraint imposed on them by monks and patriarchs. This constraint was both ethical and economic. The Byzantine emperor was accountable for the welfare of its people to the Orthodox Church, which set the standard of ethical administrative behavior. Thus, the Orthodox Church becomes the intermediary institution between the feudal elites and the imperial bureaucracy on the one hand, and the middle and lower classes on the other. It delegates the interests of the people to the elites, while using state subsidies as the source of its own financial survival.

In Byzantium the authority of the Emperor was conditioned by the approval of the Orthodox Church, and the core of the Orthodox Church itself was formed by a series of influential monastic institutions in Asia Minor, Palestine, Constantinople and Mount Athos. The relational linkages of monastic communities to landed elites - many highly ranked monks were born into feudal families - and their institutional-financial dependence on the government put the Byzantine Orthodox monastery amidst a troubled triangle of conflicting interests: the Emperor, the landed aristocracy and the people.

The influence of monastic hierarchies on state bureaucracies becomes evident when one looks more closely at the interconnections between secular and canon law. The bargaining between the emperor and the church involved an exchange in which the church intended to maximize its property privileges and the emperor his divine-based legitimacy. The emperor had the monopoly of economic regulation and the church the monopoly of spiritual legitimacy. The distinction between secular and spiritual regulation, however, was never clear-cut and often ended up in the cooptation of the church by the state.

The core of Eastern Orthodox collective as it developed in late $11^{\text {th }}-$ early $12^{\text {th }}$ century required the spiritual development of its members within a community while allowing for the emergence of charismatic individuals that would become role models for laity (Morris, 1995: 63). Charismatic leadership and hierarchy, maximization of spiritual achievement and minimization of 
material dependence constitute some of the normative rules that define the life and structure of Byzantine clergy. At the same time, if abstinence from individual property - which was the justification basis for the prohibition of marriage and lay family for Eastern Orthodox bishops and negative knowledge of God are conditions for human salvation, then the presence of a strong community is a sine qua non component for the facilitation of this salvation process (Kreismueller, 2006: 122-123).

The term epistemonarches is instrumental in understanding the elements of this interaction (Macrides, 1999: 63-65). While until the 12 th century this term was used to describe the monk who guaranteed by duty disciplinary enforcement among the members of the brotherhood, since the middle of the $12^{\text {th }}$ century it had been used in a lay context (Macrides, 1999: 63-65). Anna Komnene uses it in her masterpiece Alexiad, in order to explicitly refer to the monitoring and disciplinary capacity of her father Alexios over the patriarch of Constantinople and his hierarchical subordinates; as epistemonarches the Byzantine emperor could intervene in the hierarchy of the church both in terms of clergy appointments and legal interpretation questions (Macrides, 1999: 63-65). The treatment of ecclesiastical law as equivalent to civil imperial law and thus equally binding is only one aspect of the influence of the Orthodox Church on the Byzantine state. The resolve of the state to substitute the church in many of its functions required the creation of court offices that reflected older ecclesiastical ranks of administrative appointments or actually used clerics to perform duties that served the administrative operations of the state; for example, dikaiophylax (the law protector) and cartophylax (the records protector) are offices carried by clergymen who were accountable to the emperor, as the cases of John Zonaras and Theodore Balsamon indicate (Macrides, 1999: 71-81).

Similar patterns in the entanglement of religious and state institutions have been observed also in Kievan Rus and Muscovy. The emergence of the Trinity-Sergius monastery in the outskirts of Moscow during the second half of $14^{\text {th }}$ century and its transformation to the leading spiritual center of Russian Orthodoxy attracted - as expected - the interest of the Kremlin court and local landed elites. Sergei of Radonezh, founder of the monastery and saint, embodies many of the diachronic elements of Russian identity: abstention from wealth, prayer as a form of service to nation's military victories (battle of Kulikovo against Tatar Mamai), and holiness of community as 
reflection of the Divine Kingdom onto Russian society (Miller, 2010). The pilgrimages of Grand Prince Vasilii and Ivan the Terrible to the Trinity monastery confirm its political significance in legitimizing executive authority and explain the numerous immunity charters it enjoyed in Muscovy; despite the financial centralization undertaken by Ivan the Terrible, the Trinity's property and customs privileges were secured by 149 immunities charters between 1533 and 1605 (Miller, 2010: 76-90). Ivan's revealed preference for the non-possessor Artemii over Serapion Kurtsev for the position of Trinity abbot and the preservation - if not extension - of the monastery's privileges during the Stoglav reforms make clear that the bargain between the Church and the State has been decentralized as well as hierarchical (Miller, 2010: 89-91).

The rise of the Trinity was conditioned by the emergence of an internal administrative hierarchy that mapped the social origins of monks, since 38 percent by the middle of the $16^{\text {th }}$ century was born into a landowning family (Miller, 2010: 145-153). The hierarchy of the monastery was set up as follows: 1. Abbot, 2. Cellarer, 3. Treasurer, and 4. Bailiffs and fiscal officers (Miller, 2010: 145-153). The Trinity monastery can therefore suggest the prototype of an economic system where the abbot has the absolute managerial authority over monastic property, while he himself and his hierarchical inferiors are stripped of their formal property rights. Immediate supervision between hierarchical ranks, managerial control, familial and economic ties with nobility and landed elites, bargaining on privileges with the Moscow executive and provision of minimum subsistence to the brotherhood members form the set of definitive economic principles of the Eastern Orthodox collective.

These two pillars of Hesychast theology shaped the course of Russian orthodoxy in the early modern stages of its development. While Nil Sorsky treated monastic property and the communal provision of public goods that is financed by it as contradictory to the wisdom of early Church fathers, Joseph Volotsky understood the monastic community as a worldly institution that could perform state or quasi-state functions (Rock, 2006: 270-271). As it has been the case in Byzantium with iconoclasm, the presence of dogmatic contenders in the body of the Russian Church from $15^{\text {th }}$ to $17^{\text {th }}$ centuries made senior clergy more assertive and political in its relationship vis-à-vis the state. Under the Romanov dynasty and the growing dissemination of Protestant influences through Prussia and Holland, Russian Orthodox monasticism was seen as 
source of immorality and potential insubordination (Dixon, 2006: 339-340). The transformation of the Church into an administrative agency subject to the authority of the Tsar during the Petrine reforms of 1721 and the major secularization initiatives by Catherine the Great in the second part of the $18^{\text {th }}$ century would eliminate the influence of the Orthodox Church as an autonomous actor in Russian politics.

The duality of secular and religious power in Russian political culture is evident in the Golden Hall of the Moscow Kremlin; in his visual analysis of this space Rowland, one of the most prominent historians of Muscovite Russia, argues that it reflects the inconsistencies of the sacredprofane divide in Muscovite culture (Rowland, 2003: 33). He contends that Orthodox iconography provided a communication basis for the politics of the Court and the State; the concept of Holy Wisdom had direct reference to the authority of the autocrat, while the depiction of the Mother of God (Theotokos) to the sacred mission of the State in world affairs (Rowland, 2003: 55-57). Eastern Orthodoxy can be defined as a system of beliefs that transcend the functions of those religious institutions that created them in the first place. Orthodox monastic values in Byzantium and medieval Russia developed at the expense of executive authority as a result of an alliance between the Church and the aristocracy or landed elites. The subsequent competition between church and state either led to the formal victory of the Church and the emergence of a religiously defined bureaucratic imperialism (post-iconoclasm Byzantium) or an unstable equilibrium where the autocrat and the church were interdependent: the church depended on the continuity of economic privileges granted by the autocrat and the autocrat in return needed the support of the church as a legitimacy mechanism both in the eyes of the landed elites and aristocracy as well as the people.

The Protestantization of the Russian public space would progressively become the main challenge faced by the Russian rulers en route to their integration to the concert of Western powers. The Russian Orthodox world would perpetuate its existence in the villages and towns of the Russian Empire as well as at the lower ranks of the Russian clergy. The transition from Muscovy to Russian Empire deepened the divide between the higher and the lower strata of the Russian society and transformed Orthodoxy into a social and political identity with strong class elements. This distinction between Protestantized economic and military elites that were nominally Orthodox and the lower middle class and the peasants that represented the core of 
Eastern Orthodox values would culminate in the victory of the latter in the Russian Revolution and the consolidation of the Soviet state.

\section{The Model: Revolution and Modernization in Collectivist Societies}

\section{i. The Radical Government Game}

I now concentrate on collectivist economic systems, i.e. economies with Roman Catholic, Eastern Orthodox and Islamic majorities, as these have been historically more inclined toward revolutionary activity and abrupt political change. I setup an infinitely repeated game with two players: a leader $\Gamma$ and a citizen P. My focus is on Markov strategies, which depend only on payoff-relevant behavior, and therefore a partition of the total history of play (Maskin and Tirole, 2001).

Religion is defined as demand for public goods and is denoted with $\alpha .{ }^{2}$ Collectivist religions induce a high demand of public goods, whereas individualist religions a low demand of public goods. In the state, where there is a high probability of public goods provision, the demand for public goods is lower, as the citizens expect to receive them in the $n+1$ period. Nevertheless, in the state, where public goods provision is not likely, citizens are more pressing in their demand for public goods. Citizens care about their wage and public goods such that $U^{P}=\sum_{t=0}^{\infty} \delta^{t}\left[\left(1-\tau^{j}\right) w+\tau^{j} \omega\right]$, where $w$ denotes wage, $\tau^{j}$ denotes the provision of the public good that the leader chooses for the citizen, $\omega$ denotes the public good such that $\omega=\frac{w}{\pi}$, t indexes time, $\pi$ denotes state enforcement and $\mathrm{j}$ indexes the provision level of the public good (high or low). Moreover, the leader cares about his personal rents and the preservation of his authority. His single-period optimization problem has the following form: $\max _{\tau^{j}} r-\tau^{j} \omega$ s.t. $\tau^{j} \geq 0$, where $r$

\footnotetext{
2 Alesina, Baqir and Easterly (1999) attribute higher public goods provisions to ethnic fractionalization in Alesina Alberto, Reza Baqir and William Easterly. "Public Goods and Ethnic Divisions", Quarterly Journal of Economics, Vol. 114, No. 4 (1999): 1243-1284.
} 
denotes his rents from staying in office such that $r=e^{\pi} w$. His net present value payoff if no radical government is installed is denoted by $U^{\Gamma}=\sum_{t=0}^{\infty} \delta^{t}\left[r-\tau^{j} \omega\right]$.

The radical government game is therefore defined in the following form:

1. Players: a leader $\Gamma$ and a citizen $P$ such that $N=\{\Gamma, P\}$.

2. States: $\alpha_{t}^{I} \in\left\{\alpha_{L}^{I}=\varepsilon, \alpha_{H}^{I}=\alpha-\varepsilon\right\}$ for an individualist economic system and $\alpha_{t}^{C} \in\left\{\alpha_{L}^{C}=1-\varepsilon, \alpha_{H}^{C}=\alpha+\varepsilon\right\}$ for a collectivist economic system, where $I$ denotes an individualist economic system and $C$ a collectivist economic system, $\mathrm{H}$ denotes the high state and L denotes the low state in a collectivist and individualist economic system respectively such that $\frac{1-\alpha}{2}<\varepsilon<\alpha<1 \Rightarrow \alpha_{H}^{C}>\alpha_{H}^{I}$ and $\alpha_{L}^{C}>\alpha_{L}^{I}$.

3. Payoffs: $u^{P}=\left(1-\tau^{j}\right) w+\tau^{j} \omega$ for the citizen and $u^{\Gamma}=r-\tau^{j} \omega$ for the leader.

4. Strategies: $\Theta^{\Gamma}=\left\{\tau^{H}, \tau^{L}\right\}$ denotes the strategy set of the leader, where $\mathrm{H}$ stands for a high level of public goods provision and L stands for a low level of public goods provision such that $\tau^{L}<\tau^{H}$. The probability of citizen protest in the high state is denoted by $\eta \in\{0,1\}$ s.t. $\eta=\left\{\begin{array}{l}0 \text { if } V^{P}\left(A, \alpha_{H}^{C}, \tau^{H}\right) \geq V^{P}\left(R, \alpha_{H}^{C}\right) \\ 1 \text { if } V^{P}\left(A, \alpha_{H}^{C}, \tau^{H}\right)<V^{P}\left(R, \alpha_{H}^{C}\right)\end{array}\right.$, where A denotes authority and $\mathrm{R}$ denotes radical government.

5. Constant probabilities of switching between states $\mathrm{H}$ and $\mathrm{L}$ such that $P=\{k, 1-k\}$.

6. Discount rate $\delta$ s.t. $\delta \in(0,1)$.

$V^{P}\left(A, \alpha_{H}^{C}, \tau^{H}\right)$ is the recursive Bellman payoff for the citizen when the leader's authority is preserved and $V^{P}\left(R, \alpha_{H}^{C}\right)$ his recursive Bellman payoff when a radical government is imposed. If the citizen protests, the leader is toppled and the citizen provides the public good to himself. Because religion is fixed, there is no likelihood that a collectivist majority will turn to an 
individualist one or vice-versa. In the high collectivist payoff-dependent state the recursive payoffs of regime stability have the following form:

$V^{P}\left(A, \alpha_{H}^{C}, \tau^{j}=\tau^{H}\right)=\left(1-\tau^{H}\right) w+\tau^{H} \omega+\delta\left[k V^{P}\left(A, \alpha_{H}^{C}, \tau^{H}\right)+(1-k) V^{P}\left(A, \alpha_{L}^{C}, \tau^{L}\right)\right]$

$V^{\Gamma}\left(A, \alpha_{H}^{C}, \tau^{j}=\tau^{H}\right)=r-\tau^{H} \omega+\delta\left[k V^{\Gamma}\left(A, \alpha_{H}^{C}, \tau^{H}\right)+(1-k) V^{\Gamma}\left(A, \alpha_{L}^{C}, \tau^{L}\right)\right]$

where $\mathrm{k}$ is the probability of high state $\mathrm{H}$. The leader $\Gamma$ sets $\tau^{j}=\tau^{H}$, if $\alpha_{t}=\alpha_{H}^{C}$ and $\tau^{j}=\tau^{L}$, if $\alpha_{t}=\alpha_{L}^{C}$. The citizen is more likely to impose a radical government, when the demand for public goods rises and it is therefore harder for the leader to constrain his revolutionary activity. If radical government is imposed, then the payoffs of the leader and the citizens have the following form:

$V^{P}\left(R, \alpha_{H}^{C}=\alpha+\varepsilon\right)=\frac{\alpha+\varepsilon}{1-\delta}$

$V^{\Gamma}\left(R, \alpha_{H}^{C}=\alpha+\varepsilon\right)=0$

It is essential to point out here that $\omega=\frac{w}{\pi}$ and $r=e^{\pi} w$, where $\pi$ is bureaucratic capacity such that $\pi \in[0,1]$ and $\mathrm{w}$ denotes the market wage.

The timing of the collectivist economy game in a single-period has therefore the following structure:

1. $\alpha_{t}^{C} \in\left\{\alpha_{L}^{C}, \alpha_{H}^{C}\right\}$ is revealed.

2. The leader sets $\tau^{j} \in\left\{\tau^{L}, \tau^{H}\right\}$.

3. The citizen decides whether to protest or not: $\eta \in\{0,1\}$.

If $\eta=1$, radical government is installed.

If $\eta=0$, the leader stays in power.

Radical government can be prevented if and only if $V^{P}\left(A, \alpha_{H}^{C}, \tau^{j}=\tau^{H}\right) \geq V^{P}\left(R, \alpha_{H}^{C}=\alpha+\varepsilon\right) \Rightarrow$

$$
\begin{aligned}
& \left(1-\tau^{H}\right) w+\tau^{H} \omega+\delta\left[k V^{P}\left(A, \alpha_{H}^{C}, \tau^{H}\right)+(1-k) V^{P}\left(A, \alpha_{L}^{C}, \tau^{L}\right)\right] \geq \frac{\alpha+\varepsilon}{1-\delta} \Rightarrow \\
& \left(1-\tau^{H}\right) w+\tau^{H} \omega+\delta\left[k V^{P}\left(A, \alpha_{H}^{C}, \tau^{H}\right)+(1-k) V^{P}\left(A, \alpha_{L}^{C}, \tau^{L}\right)\right] \geq \frac{\alpha+\varepsilon}{1-\delta}
\end{aligned}
$$


It is important to note here that:

$$
\begin{aligned}
& V^{P}\left(A, \alpha_{H}^{C}, \tau^{H}\right)=\left(1-\tau^{H}\right) w+\tau^{H} \omega+\delta\left[k V^{P}\left(A, \alpha_{H}^{C}, \tau^{H}\right)+(1-k) V^{P}\left(A, \alpha_{L}^{C}, \tau^{L}\right)\right] \\
& V^{P}\left(A, \alpha_{L}^{C}, \tau^{L}\right)=w+\delta\left[k V^{P}\left(A, \alpha_{H}^{C}, \tau^{H}\right)+(1-k) V^{P}\left(A, \alpha_{L}^{C}, \tau^{L}\right)\right] \\
& V^{P}\left(A, \alpha_{H}^{C}, \tau^{H}\right)-V^{P}\left(A, \alpha_{L}^{C}, \tau^{L}\right)=-\frac{\tau^{H} w(\pi-1)}{\pi} \Rightarrow \\
& V^{P}\left(A, \alpha_{H}^{C}, \tau^{H}\right)=\left(1-\tau^{H}\right) w+\tau^{H} \omega-\frac{\tau^{H} w(\pi-1)}{\pi}-\delta k \frac{\tau^{H} w(\pi-1)}{\pi}+\delta\left[V^{P}\left(A, \alpha_{H}^{C}, \tau^{H}\right)+\frac{\tau^{H} w(\pi-1)}{\pi}\right] \Rightarrow \\
& (1-\delta) V^{P}\left(A, \alpha_{H}^{C}, \tau^{H}\right)=\left(1-\tau^{H}\right) w+\tau^{H} \frac{w}{\pi}-\frac{\tau^{H} w(\pi-1)}{\pi}-\delta k \frac{\tau^{H} w(\pi-1)}{\pi}+\delta\left[V^{P}\left(A, \alpha_{H}^{C}, \tau^{H}\right)+\frac{\tau^{H} w(\pi-1)}{\pi}\right] \Rightarrow \\
& (1-\delta) V^{P}\left(A, \alpha_{H}^{C}, \tau^{H}\right)=\left(1-\tau^{H}\right) w+\tau^{H} w \frac{[(\pi-1)(\delta(1-k)-1)+1]}{\pi} \Rightarrow \\
& (1-\delta) V^{P}\left(A, \alpha_{H}^{C}, \tau^{H}\right)=w-\tau^{H} w\left(1-\frac{[(\pi-1)(\delta(1-k)-1)+1]}{\pi}\right) \Rightarrow \\
& V^{P}\left(A, \alpha_{H}^{C}, \tau^{H}\right)=\frac{w}{1-\delta}-\frac{\tau^{H} w}{1-\delta}\left(1-\frac{[(\pi-1)(\delta(1-k)-1)+1]}{\pi}\right)
\end{aligned}
$$

Thus, the imposition of a radical government can be averted if and only if:

$$
\begin{aligned}
& \frac{w}{1-\delta}-\frac{\tau^{H} w}{1-\delta}\left(1-\frac{[(\pi-1)(\delta(1-k)-1)+1]}{\pi}\right) \geq \frac{\alpha+\varepsilon}{1-\delta} \Rightarrow \\
& w-\tau^{H} w\left(1-\frac{[(\pi-1)(\delta(1-k)-1)+1]}{\pi}\right) \geq \alpha+\varepsilon \Rightarrow \\
& \alpha \leq w-\tau^{H} w\left(1-\frac{[(\pi-1)(\delta(1-k)-1)+1]}{\pi}\right)-\varepsilon(2)
\end{aligned}
$$

Therefore, the threshold that makes the citizen indifferent between the imposition of a radical government and the preservation of the leader's authority is the following:

$$
\alpha^{*}=w-\tau^{H} w\left(1-\frac{[(\pi-1)(\delta(1-k)-1)+1]}{\pi}\right)-\varepsilon
$$

\section{Proposition 1}

There is a unique Markov perfect equilibrium of the collectivist economy game that has the following form:

1. If $\alpha \leq \pi$, then the leader preserves his authority and $\tau^{j}=\tau^{L}=0$.

2. If $\alpha>\pi$, then the imposition of a radical government is likely and the following equilibria come into play: 
a. If $\alpha \leq \alpha^{*}$, then the leader preserves his authority and $\tau^{j}=\tau^{H}$.

b. If $\alpha>\alpha^{*}$, then a radical government is imposed.

When the demand for public goods is lower than state enforcement, the leader has no incentive to provide the public good in order to stay in power. However, when the demand for public goods is higher than state enforcement, then the radical government constraint is binding and the leader needs to take action in order not to lose his office. The credibility of his commitment depends on the probability of high public goods provision in the future. If $\mathrm{k}$ is low, then the radical government becomes attractive to citizens and the leader cannot prevent it from happening.

It is important to stress here that $\alpha_{C}^{*}<\alpha_{I}^{*}$. This means that the threat for a radical government is more likely in a collectivist than in an individualist economy. This is why it is much easier for a leader of a collectivist economy to lose power. The critical threshold $\alpha_{I}^{*}$ in an individualist economy indicates that if the binding demand for public goods is higher, then in an economy with a high level of state enforcement radical government is much harder. Given that $\frac{\partial \tau^{H}}{\partial \pi}<0$, it is much cheaper for a leader in a collectivist economy to credibly commit to more public goods in the future in order to preserve his authority. Hence, he can stay in power by delivering less public goods in comparison with an individualist leader.

Historical evidence has shown that regime changes have been more frequent in states with Orthodox, Islamic and Catholic majorities. The Russian Revolution as the first major transition of the 20th century from the Russian Empire to the Soviet Union can be explained as a failure of the Imperial Russian government to acknowledge the existence of the radical government constraint and credibly commit to the provision of more public goods to the people. Similarly, the endurance of the current regime in Russia can be explained as a story of credible commitment for the provision of more public goods in the future by Putin. The horizon of this policy still remains to be seen.

The recent uprisings in the Middle East can also be explained through the lens of collectivism and its relationship with the provision of public goods. Security authoritarianism in Egypt, Tunisia, Yemen and Syria ignored the radical government constraint and persistently 
advanced high levels of inequality. Democratic consolidation in the Arab world will only occur if the governments ensuing from the demonstrations and popular dissatisfaction with the previous status quo manage to succeed where their predecessors failed: in the provision of public goods and the achievement of relative equality standards across social classes.

\section{ii. The Modernization Game}

In the radical government game, we have three possible equilibrium solutions: radical government, authority preservation with $\tau^{j}=\tau^{H}$ and authority preservation with $\tau^{j}=\tau^{L}=0$. It is now useful to refine the stage game in terms of alternatives to radical government in collectivist societies. Underdevelopment is defined as the lowest possible level of public goods provision such that $\tau^{j}=\tau^{N}$. Modernization is defined as the highest possible level of public goods provision such that $\tau^{j}=\tau^{M}$.Centralization is defined as an intermediate level of public goods provision between modernization and underdevelopment, such that $\tau^{j}=\tau^{Z}=\frac{\tau^{N}}{1-\lambda}$ and $\lambda \in\left(0,1-\frac{\tau^{N}}{\tau^{M}}\right)$. $\lambda$ denotes the extraction rate of the leader in the economy. That way, the inequality $\tau^{M}>\tau^{Z}>\tau^{N}$ holds. It is also important to mention here that the citizen prefers the public goods provision level under modernization such that $\tau^{M}=\arg \max \left(1-\tau^{j}\right) w+\tau^{j} \omega$. To prevent the likely imposition of a radical government, the leader now has three options: 1. Underdevelopment 2. Modernization and 3. Centralization.

The stage game of the collectivist economy game has now the following form:

1. $\alpha_{t}^{C} \in\left\{\alpha_{L}^{C}, \alpha_{H}^{C}\right\}$ is revealed.

2. The leader decides for or against underdevelopment: $\psi \in\{0,1\}$. Underdevelopment: $\psi=1$.

3. If $\psi=0$, the leader decides between modernization and centralization: $\zeta \in\{0,1\}$. Modernization: $\zeta=1$ and centralization: $\zeta=0$.

4. The citizen decides whether to protest or not against the government: $\eta \in\{0,1\}$.

If $\eta=1$, a radical government is installed. 
If $\eta=0$, the leader stays in power and the provision level of public goods is his choice from the set $\mathrm{H}^{\Gamma}=\left\{\tau^{N}, \tau^{Z}, \tau^{M}\right\}$.

Like in the previous section, prevention of a radical government in a collectivist society relies on the ability of the leader to convince the citizen that he will credibly commit to the provision of public goods in the future. The difference from the previous section is that here the leader has an additional third option, centralization, which depends on his extraction rate over the economy. That means that the leader may be interested in providing more public goods compared to underdevelopment but not as much as it would be the case under modernization.

In many authoritarian regimes, the ability of the leader to collect personal rents for the public and the private sector of the economy defines his tenure horizon. A leader who is successful in maintaining a high extraction rate over the economy may be more inclined to provide more public goods to the citizen in order to stay in power. This is the upward side of authoritarian stability. Nevertheless, the citizen may be empowered enough to challenge the leader, because the provision of public goods does not meet his normative priors. Then the leader may have to resort to the lowest possible provision of public goods in order to discipline the citizen and avoid a radical government threat in the future.

The dynamic payoffs for underdevelopment, centralization and modernization in collectivist societies have therefore the following form:

\section{Underdevelopment}

$$
\begin{aligned}
& V^{\Gamma}\left(U, \alpha_{H}^{C}=\alpha+\varepsilon, \tau^{j}=\tau^{N}\right)=r-\tau^{N} \omega+\delta\left[k V^{\Gamma}\left(U, \alpha_{H}^{C}, \tau^{N}\right)+(1-k) V^{\Gamma}\left(N, \alpha_{L}^{C}\right)\right] \\
& V^{P}\left(U, \alpha_{H}^{C}=\alpha+\varepsilon, \tau^{j}=\tau^{N}\right)=\left(1-\tau^{N}\right) w+\tau^{N} \omega+\delta\left[k V^{P}\left(U, \alpha_{H}^{C}, \tau^{N}\right)+(1-k) V^{P}\left(N, \alpha_{L}^{C}\right)\right]
\end{aligned}
$$

\section{Centralization}

$$
\begin{aligned}
& V^{\Gamma}\left(Z, \alpha_{H}^{C}=\alpha+\varepsilon, \tau^{j}=\tau^{Z}\right)=(1+\pi)\left(r-\tau^{Z} \omega\right)+\delta V^{i}\left(Z, \alpha_{H}^{C}, \tau^{Z}\right)=\frac{(1+\pi)\left(r-\tau^{Z} \omega\right)}{1-\delta} \\
& V^{P}\left(Z, \alpha_{H}^{C}=\alpha+\varepsilon, \tau^{j}=\tau^{Z}\right)=(1-\pi)\left[\left(1-\tau^{Z}\right) w+\tau^{Z} \omega\right]+\delta V^{i}\left(Z, \alpha_{H}^{C}, \tau^{Z}\right)=\frac{(1-\pi)\left[\left(1-\tau^{Z}\right) w+\tau^{Z} \omega\right]}{1-\delta}
\end{aligned}
$$

\section{Modernization}


$V^{\Gamma}\left(M, \alpha_{H}^{C}=\alpha+\varepsilon, \tau^{j}=\tau^{M}\right)=\frac{r-\tau^{M} \omega}{1-\delta}$
$V^{P}\left(M, \alpha_{H}^{C}=\alpha+\varepsilon, \tau^{j}=\tau^{M}\right)=\frac{\left(1-\tau^{M}\right) w+\tau^{M} \omega}{1-\delta}$

From the aforementioned payoffs it becomes clear that modernization persists in the future, once it is implemented. This commitment device is the only sufficient way that the leader has to prevent revolutionary activity, when the citizen is determined to protest against him and thus replace him with self-provision of the public good. Modernization suggests the credible promise of the leader that he will continue to deliver the highest possible amount of public goods in the future. On the contrary, underdevelopment does not offer any guarantee for continued provision of public goods in the future. The leader can either continue with the provision of the public good at $\tau^{j}=\tau^{N}$ or stop delivering the public good to the citizen. For the citizen underdevelopment entails the reversal threat to the state of backwardness where no public good is provided. This is why he will always prefer modernization to underdevelopment in order not to stage a protest and undermine the leader's power. The leader will always try to avert a radical government with the lowest possible level of public goods provision. Because this may not always be the case with underdevelopment, I introduce here an intermediate level in the provision of public goods, centralization. An interesting aspect in modeling centralization is that it also repeats itself infinitely once chosen by the leader. As it is the case with modernization, the leader promises that he will not revert to backwardness after centralization is chosen. This is the case because that way the leader reduces the probability of radical government without having to resort to the costlier solution of modernization. Post-Soviet Russia under Putin and China under the continued political control of the Communist Party are useful paradigms that justify the design of centralization as a distributive commitment device.

We know that the leader always prefers underdevelopment to modernization. It is now important to the set the threshold value for $\lambda$ that makes the leader indifferent between underdevelopment and centralization:

$V^{\Gamma}\left(U, \alpha_{H}^{C}=\alpha+\varepsilon, \tau^{j}=\tau^{N}\right) \geq V^{\Gamma}\left(Z, \alpha_{H}^{C}=\alpha+\varepsilon, \tau^{j}=\tau^{Z} \mid \lambda\right)(4)$

I then find the recursive payoff of the leader in underdevelopment: 


$$
\begin{aligned}
& V^{\Gamma}\left(U, \alpha_{H}^{C}=\alpha+\varepsilon, \tau^{N}\right)=W^{\Gamma}\left(\tau^{N}\right)+\delta\left[k V^{i}\left(U, \alpha_{H}^{C}, \tau^{N}\right)+(1-k) V^{i}\left(N, \alpha_{L}^{C}\right)\right] \Rightarrow \\
& V^{\Gamma}\left(U, \alpha_{H}^{C}=\alpha+\varepsilon, \tau^{N}\right)=e^{\pi} w-\tau^{N} \frac{w}{\pi}+\delta\left[k V^{i}\left(U, \alpha_{H}^{C}, \tau^{N}\right)+(1-k) V^{i}\left(N, \alpha_{L}^{C}\right)\right] \\
& V^{\Gamma}\left(N, \alpha_{L}^{C}=1-\varepsilon\right)=e^{\pi} w+\delta\left[k V^{i}\left(U, \alpha_{H}^{C}, \tau^{N}\right)+(1-k) V^{i}\left(N, \alpha_{L}^{C}\right)\right] \\
& V^{\Gamma}\left(U, \alpha_{H}^{C}=\alpha+\varepsilon, \tau^{N}\right)-V^{\Gamma}\left(N, \alpha_{L}^{C}=1-\varepsilon\right)=-\frac{\tau^{N} w}{\pi} \\
& V^{\Gamma}\left(U, \alpha_{H}^{C}=\alpha+\varepsilon, \tau^{N}\right)=e^{\pi} w-\frac{\tau^{N} w}{\pi}-\delta k \frac{\tau^{N} w}{\pi}+\delta V^{\Gamma}\left(U, \alpha_{H}^{C}=\alpha+\varepsilon, \tau^{N}\right)+\delta \frac{\tau^{N} w}{\pi} \Rightarrow \\
& (1-\delta) V^{\Gamma}\left(U, \alpha_{H}^{C}=\alpha+\varepsilon, \tau^{N}\right)=e^{\pi} w-\frac{\tau^{N} w}{\pi}-\delta k \frac{\tau^{N} w}{\pi}+\delta \frac{\tau^{N} w}{\pi} \Rightarrow \\
& (1-\delta) V^{\Gamma}\left(U, \alpha_{H}^{C}=\alpha+\varepsilon, \tau^{N}\right)=e^{\pi} w-\frac{\tau^{N} w}{\pi}[1+\delta(k-1)] \Rightarrow V^{\Gamma}\left(U, \alpha_{H}^{C}=\alpha+\varepsilon, \tau^{N}\right)=\frac{e^{\pi} w}{1-\delta}-\frac{\tau^{N} w}{\pi(1-\delta)}[1+\delta(k-1)]
\end{aligned}
$$

I now return to (5):

$$
\begin{aligned}
& V^{\Gamma}\left(U, \alpha_{H}^{C}=\alpha+\varepsilon, \tau^{j}=\tau^{N}\right) \geq V^{\Gamma}\left(Z, \alpha_{H}^{C}=\alpha+\varepsilon, \tau^{j}=\tau^{Z} \mid \lambda\right) \Rightarrow \\
& \frac{e^{\pi} w}{1-\delta}-\frac{\tau^{N} w}{\pi(1-\delta)}[1+\delta(k-1)] \geq \frac{(1+\pi)\left(e^{\pi} w-\frac{\tau^{N} w}{(1-\lambda) \pi}\right)}{1-\delta} \Rightarrow e^{\pi} w-\frac{\tau^{N} w}{\pi}[1+\delta(k-1)] \geq(1+\pi)\left(e^{\pi} w-\frac{\tau^{N} w}{(1-\lambda) \pi}\right) \Rightarrow \\
& e^{\pi}-\frac{\tau^{N}}{\pi}[1+\delta(k-1)] \geq(1+\pi)\left(e^{\pi}-\frac{\tau^{N}}{(1-\lambda) \pi}\right) \Rightarrow-\frac{\tau^{N}}{\pi}[1+\delta(k-1)] \geq \pi e^{\pi}-\frac{\tau^{N}(1+\pi)}{(1-\lambda) \pi} \Rightarrow \\
& \frac{\tau^{N}(1+\pi)}{1-\lambda} \geq \pi^{2} e^{\pi}+\tau^{N}[1+\delta(k-1)] \Rightarrow \frac{\tau^{N}(1+\pi)}{\pi^{2} e^{\pi}+\tau^{N}[1+\delta(k-1)]} \geq 1-\lambda \Rightarrow \\
& \lambda \geq 1-\frac{\tau^{N}(1+\pi)}{\pi^{2} e^{\pi}+\tau^{N}[1+\delta(k-1)]}
\end{aligned}
$$

Hence, the threshold value of $\lambda$ is defined by the following equation:

$$
\lambda^{*}=1-\frac{\tau^{N}(1+\pi)}{\pi^{2} e^{\pi}+\tau^{N}[1+\delta(k-1)]}
$$

This means that if $\lambda \geq \lambda^{*}$, then the leader prefers underdevelopment to centralization, whereas the opposite holds if $\lambda<\lambda^{*}$.

I now set the threshold value that makes the citizen indifferent between radical government and modernization, given that $\tau^{M}=\arg \max \left(1-\tau^{j}\right) w+\tau^{j} \omega$ : 


$$
\begin{aligned}
& V^{P}\left(M, \alpha_{H}^{C}=\alpha+\varepsilon, \tau^{j}=\tau^{M}\right) \geq V^{P}\left(R, \alpha_{H}^{C}=\alpha+\varepsilon\right) \Rightarrow \\
& \frac{\left(1-\tau^{M}\right) w+\tau^{M} \omega}{1-\delta} \geq \frac{\alpha+\varepsilon}{1-\delta} \Rightarrow\left(1-\tau^{M}\right) w+\tau^{M} \omega \geq \alpha+\varepsilon \Rightarrow \\
& \left(1-\tau^{M}\right) w+\tau^{M} \omega-\varepsilon \geq \alpha \Rightarrow \alpha \leq w\left[1+\tau^{M}\left(\frac{1}{\pi}-1\right)\right]-\varepsilon
\end{aligned}
$$

Thus, the threshold value for the demand of public goods has the following form:

$\alpha^{*}=w\left[1+\tau^{M}\left(\frac{1}{\pi}-1\right)\right]-\varepsilon(6)$

This means that if $\alpha \leq \alpha^{*}$, then the citizen is not likely to impose a radical government, and if $\alpha>\alpha^{*}$, then the radical government is likely to be imposed.

\section{Proposition 2}

There is a unique Markov perfect equilibrium of the collectivist economy game that has the following form:

1. If $\alpha \leq \pi$, then the leader remains unchallenged. Backwardness persists.

2. If $\alpha>\pi$, then the radical government constraint is binding and the following equilibria are observed:

a. If $\alpha \leq \alpha^{*}$ and $\lambda^{*} \leq \lambda$ or $\alpha>\alpha^{*}$ and $\lambda^{*}>\lambda$, then the leader chooses underdevelopment:

$$
\tau^{j}=\tau^{N}
$$

b. If $\alpha \leq \alpha^{*}$ and $\lambda^{*}>\lambda$, then the leader chooses centralization: $\tau^{j}=\tau^{Z}$.

c. If $\alpha>\alpha^{*}$ and $\lambda^{*} \leq \lambda$, then the leader chooses modernization: $\tau^{j}=\tau^{M}$.

In a collectivist society, when the citizen is not likely to protest against the leader and thus install a radical government that will oust him, then the leader chooses between his two most favorable provision levels: underdevelopment and centralization. His choice depends on the value of the exogenously defined $\lambda$ and whether it above or below his indifference threshold $\lambda^{*}$. Nevertheless, when the citizen finds the imposition of a radical government attractive, the leader is obliged to follow one of the two corner choices of his strategy set in order to stay in power: underdevelopment or modernization. Under the threat of a radical government and a belowthreshold extraction rate, the leader chooses underdevelopment, because centralized distribution transmits the wrong information to the citizen and thus encourages radical government. The 
leader knowing that will offer to the citizen the lowest possible provision level (underdevelopment) as a form of punishment, such that as $\lim _{\lambda \rightarrow 0} \tau^{Z}=\tau^{N}$. Similarly, when a radical government is imminent and the leader has a high extraction rate over the economy, the citizen will not be willing to accept even the modernization provision level of the public good. The provision level of the public good under centralization is costly and likely to further encourage radical government. The leader knowing that will choose modernization in order to preserve his authority such that $\lim _{\lambda \rightarrow 1-\frac{\tau^{N}}{\tau^{M}}} \tau^{Z}=\tau^{M}$.

\section{Comparative Statics}

In the analysis of the equilibrium comparative statics I explore the relationship between state enforcement and modernization. For high levels of state enforcement, modernization does not occur because the threat of radical government is not binding. I take the derivative of $\alpha^{*}$ such that: $\frac{\partial \alpha^{*}}{\partial \pi^{*}}=\frac{\partial \tau^{M}}{\partial \pi^{*}}\left(\frac{1}{\pi^{*}}-1\right)-\tau^{M} \frac{1}{\pi^{* 2}}<0$

where $\pi^{*}$ denotes a critical threshold of state enforcement. It is obvious that if $\pi^{*} \geq \pi$, modernization is selected by the leader. He cannot use his mechanisms of surveillance and control to reduce the provision level of the public good in order to stay in power. Thus, he needs to offer a higher provision level for that end. Furthermore, I take also the derivative of $\lambda^{*}$ such that:

$$
\frac{\partial \lambda^{*}}{\partial \bar{\pi}}=\frac{e^{\pi} \bar{\pi}\left[(1+\bar{\pi})\left(2 \tau^{N}-\frac{\partial \tau^{N}}{\partial \bar{\pi}}\right)+\bar{\pi} \tau^{N}\right]-\left(\tau^{N}\right)^{2}[1+\delta(k-1)]}{\left[e^{\pi} \bar{\pi}^{2}+\tau^{N}[1+\delta(k-1)]\right]^{2}}>0
$$

where $\bar{\pi}$ denotes a second critical threshold of state enforcement such that $\pi^{*}<\bar{\pi}$. A higher capacity for state enforcement reduces the provision level for underdevelopment and thus makes centralization a more attractive option for the leader who wants to extend his tenure horizon. Higher state enforcement helps the leader to increase his extraction rents from the economy and offer more public goods to the citizen without any rising threat for radical government. Thus, centralization occurs if $\pi>\bar{\pi}$. Underdevelopment occurs at intermediate levels of state enforcement. When state enforcement is too high, the leader is better off by choosing 
centralization; by providing the public good at the centralization rather than at the underdevelopment level he minimizes the threat of a radical government in the future. When state enforcement is too low, the leader chooses modernization, because in that case the demand threshold of the citizen is too high and thus it is less costly to provide $\tau^{M}$.

\section{Lemma 2}

In the collectivist economy game there is a negative monotonic relationship between state enforcement and modernization. When $\pi^{*} \geq \pi$, modernization is selected by the leader. When $\pi>\bar{\pi}$, the leader opts for centralization. Underdevelopment occurs at intermediate levels of state enforcement such that $\pi^{*}<\pi \leq \bar{\pi}$.

Modernization occurs when the state credibly promises to provide a sufficient amount of public goods to its citizens at low levels of state enforcement. Because the leader opts for modernization when $\lambda^{*} \leq \lambda$, modernization is more likely the lower $\lambda^{*}$ is. The inverse holds for centralization; the higher $\lambda^{*}$ is, the more likely is the leader to opt for centralization. Underdevelopment reflects the choice of a leader, who is not too weak to give in to the demand of the citizen in order to prevent a radical government, but he is also not too strong, in order to prefer centralization to underdevelopment for the preservation of his authority. Putin's Russia and contemporary China are typical cases of centralization, whereas underdevelopment holds for the majority of states in the Middle East and the former Soviet Union. Modernization was about to occur in the 1990s in Russia but the effort collapsed when state enforcement approximated zero. This is a useful lesson for the Arab states that decided to pave their way toward democracy and the rule of law; state enforcement needs to be low but it has to exist.

\section{Conclusions}

My theory suggests that religious norms define the demand for public goods that citizens want from the leader to avoid protesting against him and therefore imposing a radical government that will satisfy their demand for public goods. Islam, Orthodoxy and Catholicism are defined as collectivist religions, because they induce a higher demand for public goods, while Protestantism and Judaism as individualist religions, because they induce a lower demand for public goods. The proposed taxonomy here expands this dichotomous distinction. Modernization occurs as 
commitment mechanism proposed by the leader to his citizens in order to maintain his post and stay in power. The regime outcome depends on the occurrence of modernization and the ability of the leader to meet the demand of citizens for public goods.

Religion does not matter only as a set of normative rules that define the human relationship to God. In this paper, I argue that religion is important as a political-economic phenomenon. Because world religions have different socio-economic prerogatives about resource distribution and community organization, they condition different types of economic systems and political regimes. The comparative study of the Eastern Orthodox monastery and the Jewish kibbutz as economic systems cannot be easily separated from the political and economic environment that led to their emergence and transformation. Nevertheless, it provides evidence on resource distribution in religious collectives and the extent to which religious norms influence individual and collective welfare. The effects of religion on political regimes are studied in the form of tradeoffs between hierarchy and incentives; in particular between market wage opportunity cost and social insurance in the Jewish kibbutz, between obedience and individual profit in the Eastern Orthodox monastery.

State formation and economic transition have always relied on extractive public administrations and a mobilized citizenry. This paper is one of the first studies that place religion in the epicenter of this stylized transformative process. The radical government and modernization games that I propose for collectivist economic systems have common grounds: the elaboration of conditions under which the leader manages to preserve his authority, when the imposition of a radical government by the citizen is likely. In states with collectivist religious majorities, modernization occurs at levels of low state enforcement and the emergence of a radical government is always likely. Centralization is the leader's choice when he can afford to provide more public goods to his citizens at high levels of state enforcement. That way, he manages to preserve his authority without having to make major concessions in the future. 


\section{References}

Abramitzky Ram. "The Limits of Equality: Insights from the Israeli Kibbutz", Quarterly Journal of Economics, 123:3, 1111-1159, August 2008.

Acemoglu Daron and James Robinson. "On the economic origins of democracy", Daedalus, Winter 2007, 160-162.

Acemoglu Daron and James Robinson. Economic Origins of Dictatorship and Democracy, Cambridge University Press, 2006.

Acemoglu Daron. "Why not a political Coase Theorem? Social conflict, commitment, and politics", Journal of Comparative Economics, Vol. 31, No. 4 (December 2003): 620-652.

Alesina Alberto, Reza Baqir and William Easterly. "Public Goods and Ethnic Divisions", Quarterly Journal of Economics, Vol. 114, No. 4 (1999): 1243-1284.

Amiel Yoram et al. "Inequality among the Kibbutzim", Economica, New Series, Vol. 63, No. 250, Supplement: Economic Policy and Income Distribution (1996): 63-85.

Cremer Helmuth and Pierre Pestieau. "Social Insurance Competition between Bismarck and Beveridge", Journal of Urban Economics, Vol. 54 (2003): 181-196.

Desai Raj M, Anders Olofsgard, and Tarik M. Yousef. "The Logic of Authoritarian Bargains", Economics \& Politics, Vol. 21, No. 1 (March 2009): 93-125.

Dixon Simon. "The Russian Orthodox Church: 1721-1917" in Angold Michael. The Cambridge History of Eastern Christianity, Vol. 5, Cambridge University Press, 2006.

Eckstein Harry. Regarding Politics: Essays on Political Theory, Stability and Change, University of California Press, Berkeley and Los Angeles, 1992.

Eisenstadt S.N. "Israeli Identity: Problems in the Development of the Collective Identity of an Ideological Society", Annals of the American Academy of Political and Social Science, 1967, 370: 115-123.

Fishman Ariyei and Yaaqov Goldschmidt. "The Orthodox Kibbutzim and Economic Success", Journal for the Scientific Study of Religion, Vol. 29, No. 4, December 1990: 505-511.

Fishman Aryei. "Judaism and Modernization: The Case of the Religious Kibbutzim", Social Forces, Vol. 62, No. 1 (1983): 9-31.

Gerschenkron Alexander, Economic Backwardness in Historical Perspective: A Book of Essays, Frederick A. Praeger Publishers, 1965.

Greif Avner. "Cultural beliefs and the organization of society: A historical and theoretical reflection on collectivist and individualist societies", Journal of Political Economy, Vol. 102, No. 5 (October 1994): 912-950.

Helman Amir. "The Israeli Kibbutz as a Socialist Model", Journal of Institutional and Theoretical Economics, Vol. 148, No. 1, The New Institutional Economics East European Reconstruction Problems (March 1992): 168-183.

Huntington S.P. Political Order in Changing Societies, Yale University Press, 1968.

Inglehart R and WE Baker, "Modernization, cultural change and the persistence of traditional values", American Sociological Review, Vol. 65, No. 1 (February 2000): 19-51.

Kleiman Ephraim. “The Waning of Israeli Etatisme” Israel Studies, Vol. 2, No. 2 (Fall 1997): 146-171.

Kreismueller Dirk. "The rise of Hesychasm" in Angold Michael. The Cambridge History of Eastern Christianity, Vol. 5, Cambridge University Press, 2006. 
Lipset Seymour Martin. "Culture and Economic Behavior: A Commentary", Journal of Labor Economics, Vol. 11, No. 1, Part 2: U.S. and Canadian Income Maintenance Programs (January 1993): 343-S345.

Lipset SM, "Some social requisites of democracy: Economic development and political legitimacy", American Political Science Review, Vol. 53, No. 1 (March 1959): 69-105.

Macrides R.J. "Nomos and Kanon in Paper and in Court" in Kinship and Justice in Byzantium, 11 th-15 th Centuries, Variorum Collected Studies Series, 1999.

Maskin Eric and Jean Tirole. "Markov Perfect Equilibrium I. Observable Actions", Journal of Economic Theory, Vol. 100, (2001): 191-219.

Meyendorff John. "Byzantine Theology: Historical Trends and Doctrinal Themes”, Fordham University Press, New York, 1974.

Miller David B. "Saint Sergius of Radonezh, His Trinity Monastery and the Formation of Russian Identity", Northern Illinois University Press, 2010.

Morony Michael G. "Religious Communities in Late Sasanian and Early Muslim Iraq", Journal of the Economic and Social History of the Orient, Vol. 17, No. 2, May 1974: 113-135, at 131.

Morris Rosemary. Monks and Laymen in Byzantium, 843-1118. Cambridge University Press, 1995.

Putterman Louis. "Incentives and the Kibbutz: Toward an Economics of Communal Work Motivation", Journal of Economics, Vol. 43 (1983), No. 2: 157-188.

Rock Stella. "Russian piety and Orthodox culture" in Angold Michael. The Cambridge History of Eastern Christianity, Vol. 5, Cambridge University Press, 2006.

Rostow WW, “The Stages of Economic Growth”, Economic History Review, Vol. 12, No. 1 (1959): 1-16.

Rowland Daniel. "Two Cultures, One Throne Room: Secular Courtiers and Orthodox Culture in the Golden Hall of the Moscow Kremlin" in Kivelson Valerie A. and Robert H. Greene. Orthodox Russia: Belief and Practice under the Tsars, The Penn State University Press, 2003.

Ruffle Bradley J. and Richard Sosis. "Cooperation and the in-group-out-group bias: A field test on Israeli kibbutz members and city residents", Journal of Economic Behavior and Organization, Vol. 60 (2006) 147-163.

Schemann Alexander. "The Historical Road of Eastern Orthodoxy", Holt, Rinehart and Winston, New York, Chicago and San Francisco, 1963.

Schwartz Richard. "Democracy and Collectivism in the Kibbutz", Social Problems, Vol. 5, No. 2, Special Issue on the Kibbutz (Autumn, 1957): 137-147.

Weber, Max. The Protestant Ethic and "The Spirit of Capitalism", translated by Peter Baehr and Gordon C. Wells, Penguin Books, 2002.

Weisman J. “The Kibbutz: Israel's Collective Settlement”, 1 Israel Law Review 99, 1996. 


\section{APPENDIX}

\section{Theoretical Taxonomy}

I propose multiple regime outcomes as equilibrium solutions such as public sector (Byzantine) oligarchy in Orthodoxy, liberal or social democracy in Protestantism, state corporatism or clientelism in Catholicism, entrepreneurial aristocracy in Islam, and fragmented democracy in Judaism. The following 5-by-3 matrix is indicative of my scheme on the interaction between religion and economic development and their sequential effect on political regimes:

Table 1

\begin{tabular}{|c|c|c|c|}
\hline Development $\rightarrow$ & Backwardness & Economic System & Political Regime \\
\hline Religion $\downarrow$ & & & \\
\hline Protestantism & Constrained Leadership & Liberal/Social Democracy & Representative Democracy \\
\hline Judaism & Stateless Cosmopolitanism & Regulated Capitalism & Fragmented or Religious Democracy \\
\hline Catholicism & Unconstrained Kingship & State Corporatism/Clientelism & Interest-group Democracy or Fascism \\
\hline Orthodoxy & Bureaucratic Imperialism & Byzantine Oligarchy & $\begin{array}{l}\text { Clan Democracy or Communism or } \\
\text { Surveillance Authoritarianism }\end{array}$ \\
\hline Islam & Normative Imperialism & Entrepreneurial Aristocracy & $\begin{array}{l}\text { Islamic Plurality or Theocracy or } \\
\text { Security Authoritarianism }\end{array}$ \\
\hline
\end{tabular}

In constrained leadership, the head of state is constrained by a council of nobles or a judicial apparatus. The Protestant principles of self-help and hard work apply in an economic system where the private sector is relatively independent from the state and the government is committed to a minimum level of social welfare - 18 ${ }^{\text {th }}$ century British Empire, Bismarckian Germany - (Cremer and Pestieau, 2003).

As liberal/social democracy is defined a Protestant market economy, where regular elections, extensive civil rights, and a grown private sector are complemented by welfare provisions (United States, United Kingdom, Sweden, Denmark, Norway, Finland, post-war Germany, Netherlands). The dichotomy between liberal and social democracy depends on the balance between social welfare and civil rights in both constitutional design and public policy. Representative democracy is the political equivalent of liberal or social democracy. Protestant countries are the least likely to transition to a nondemocratic form of government. 
Stateless cosmopolitanism designates the unique situation of Jews in East-Central Europe and the Near East. Absence of formal state structures is combined with solid community development and professional activity in the private sector. Exclusion from the wider public sector constrained conversion to the majority's religion and facilitated the preservation of Jewish social values.

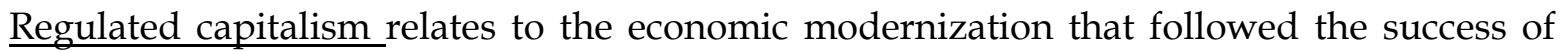
the Zionist movement and the emergence of the state of Israel. Government intervention is less intensive than in continental economies of Western Europe and Soviet central planning (Kleiman, 1997). Trade protection, discriminatory taxation and capital market regulation have been some of the basic elements of Israeli economy that reflected the need for the political consolidation of the Jewish state in the territories of British Mandate Palestine (Kleiman, 1997).

Unconstrained kingship implies the existence of a royal institution that is not subject to any effective checks and balances; welfare provision has explicit divine and/or administrative origins and reflects the moral prerogatives of the Roman Catholic Church (royal Spain, Austrian Empire, French Ancien Regime).

State corporatism/clientelism includes competitive or quasi-competitive elections and the protection of a minimum of civil rights. Although social welfare provisions reflect Roman Catholic norms, they are aimed more toward electoral rents for the incumbent rather than toleration of administrative arbitrariness (Brazil, Spain, Italy, France, Belgium, Austria). Interest-group democracy and fascism are treated as the democratic and authoritarian mirrors of state corporatism/clientelism.

Bureaucratic imperialism implies that the state is committed to territorial and economic expansion through administrative means; there is a cooptation of the religious institutions by the state. Religious conversion is not necessary, although desirable (Byzantine Empire, Muscovy, Russian Empire).

Byzantine oligarchy entails an oversized public sector and either nominal or real electoral rules for the appointment of governments. The state regulates the economy and the private sector is both institutionally and materially dependent on the government. A high demand for public goods provision continues to reflect the Eastern Orthodox norms of hierarchical organization at 
the expense of transparency and lack of corruption (Soviet Union, Russia, Ukraine, Bulgaria, Romania, Serbia, Greece). There is a multiplicity of political regime types that can be attached to Byzantine oligarchy: communism, surveillance authoritarianism and clan democracy.

Normative imperialism implies a conflation of religious values and the state with the objective of territorial and economic expansion through administrative means. Hence, the head of state is also the highest moral authority in the government; the provision of public goods occurs more through corporate channels than the bureaucracy itself. Social welfare manifests the Islamic norms of solidarity and protection of the poor against injustices committed by the rich (Pahlavi Iran, Safavid Persia, Ottoman Empire).

Entrepreneurial aristocracy suggests the prevalence of corporate elites, in the public or the private sector, who are appointed directly or indirectly by the government. Enterprises fulfill public functions and commit to the provision of public goods that advance regime endurance (Islamic Iran, modern Turkey, Egypt, Indonesia, Malaysia). Security authoritarianism, theocracy and Islamic plurality are the regime types corresponding to entrepreneurial aristocracy as an economic system. By Islamic plurality I mean a representative form of government, which meets the basic procedural criteria of democracy and stresses the significance of religious law in public affairs, which usually comes at the expense of the rights of non-Muslim minorities. 


\section{Diskussionsbeiträge - Fachbereich Wirtschaftswissenschaft - Freie Universität Berlin Discussion Paper - School of Business and Economics - Freie Universität Berlin}

2013 bereits erschienen:

2013/1 MASSARRAT-MASHHADI, Nima

The mutual impact of deferral labour taxation and capital income taxation on risk-taking behaviour : an experimental analysis

FACTS

2013/2 ENGLER, Philipp und Simon VOIGTS

A Transfer Mechanism for a Monetary Union

Economics

2013/3 CHADI, Adrian und Clemens HETSCHKO

Flexibilisation without Hesitation? : temporary contracts and workers' satisfaction

Economics

2013/4 HOLTFRERICH, Carl-Ludwig

Government Debt in Economic Thought of the Long 19th Century

Economics

2013/5 BESTER, Helmut und Daniel KRÄHMER

Exit Options and the Allocation of Authority

Economics

2013/6 BESTER, Helmut und Johannes Münster

Subjective Evaluation versus Public Information

Economics

2013/7 JENDERNY, Katharina

Mobility of Top Incomes in Germany

Economics

2013/8 SKUPNIK, Christoph

"Welfare magnetism" in the EU-15? : why the EU enlargement did not start a race to the bottom of welfare states

Economics

2013/9 MUCHLINSKI, Elke

Die Unzweckmäßigkeit physikalischer Metaphern und Begriffe für die Ökonomie als Erfahrungswissenschaft

Economics

2013/10 SCHREIBER, Sven

(When) Does Money Growth Help to Predict Euro-area Inflation at Low Frequencies?

Economics

2013/11 KNOLL, Martin

The Heavily Indebted Poor Countries and the Multilateral Debt Relief Initiative :

a Test Case for the Validity of the Debt Overhang Hypothesis

Economics 
$2013 / 12$

CORNEO, Giacomo

Work Norms, Social Insurance and the Allocation of Talent

Economics

2013/13 GRIGORIADIS, Theocharis und Benno TORGLER

Religious Identity, Public Goods and Centralization : Evidence from Russian and Israeli Cities

Economics

2013/14 GRIGORIADIS, Theocharis

A Political Theory of Russian Orthodoxy Evidence from Public Goods

Experiment

Economics

2013/15 HECHTNER, Frank

Ökonomische Anreizwirkungen im bundesstaatlichen Finanzausgleich FACTS 